\title{
MONITORING OF MICROBIAL INDICATOR GROUPS IN CAVES THROUGH THE USE OF RIDA ${ }^{\oplus}$ COUNT KITS
}

\section{MONITORING MIKROBNIH INDIKATORSKIH SKUPIN V JAMAH Z UPORABO BIOLOŠKEGA KOMPLETA RIDA ${ }^{\circ} \mathrm{COUNT}$}

\author{
Janez MULEC ${ }^{1}$, Václav KRIŠTƯFEK² \& Alica CHROŇÁKOVÁ
}

\begin{abstract}
UDC 551.435.84:579.2

Janez Mulec, Václav Krištůfek \& Alica Chroñáková: Monitoring of microbial indicator groups in caves through the use of RIDA ${ }^{\circ}$ COUNT kits

Measurements of microbiological parameters are not currently widely used for protection, monitoring and preservation of caves although they indicate very well the recent human impact. Here we present a commercially available microbiological kit for cave ecologists, the RIDA ${ }^{\circ} \mathrm{COUNT}$ test kit (R-Biopharm AG, Germany), as a supplementary tool for research and show examples. Simultaneously, lists of microbial indicator groups and cave microhabitats, where this methodology may be applied, are presented. Indicators include certain clinically important human-associated microbes such as Escherichia coli, Salmonella spp. and Staphylococcus aureus that are easy to quantify with basic cultivation methodology. Relatively higher bacterial counts compared to yeast and moulds on RIDA ${ }^{\circ} \mathrm{COUNT}$ test plates indicate recent and pronounced human impact. Swab samples allow detection of gradients of surface microbial colonization and determination of the microbial load on footprints and fingerprints in caves. In our tests, RIDA ${ }^{\circ} \mathrm{COUNT}$ plates for enumeration of yeast and moulds revealed a similar microbial load between unwashed caving boots and human fingerprints on a metal fence. Similarly, total bacterial counts were comparable between these two surfaces, $5,890 \mathrm{CFU} / 100 \mathrm{~cm}^{2}$ for unwashed boots and $4,340 \mathrm{CFU} / 100 \mathrm{~cm}^{2}$ for fingerprints on metal fence. Bacterial counts on walking surfaces in show caves can exceed 10,000 CFU/100 $\mathrm{cm}^{2}$ (Postojna Cave). These examples show that quantification of microbial indicator groups revealed increased microbial load and possible biohazard in the underground. This procedure may be widely adopted as a part of a regular monitoring programme in caves.
\end{abstract}

Keywords: caves, microorganisms, monitoring, human impact, water quality.

\author{
Izvleček \\ UDK 551.435.84:579.2 \\ Janez Mulec, Václav Krištůfek \& Alica Chroñáková: Moni- \\ toring mikrobnih indikatorskih skupin $v$ jamah $z$ uporabo \\ biološkega kompleta RIDA ${ }^{\circ}$ COUNT
}

Merjenje mikrobioloških parametrov se ne uporablja pogosto $\mathrm{v}$ smislu zaščite, monitoringa in ohranjanja jam, čeprav v veliki meri nakazujejo nedaven vpliv človeka v podzemlju. $V$ članku predstavljamo komercialno dostopen RIDA ${ }^{\circ} \mathrm{COUNT}$-ov mikrobiološki komplet (R-Biopharm AG, Nemčija) in primere uporabe le-tega za jamske ekologe, ki jim lahko služi kot pomožno orodje pri raziskavah. $\mathrm{V}$ prispevku navajamo tudi seznam mikrobnih indikatorskih skupin in jamskih mikrohabitatov, kjer se to metodologijo lahko uporabi. Indikatorji vključujejo nekatere klinično pomembne mikrobe, ki so povezani s človekovim zdravjem, kot so Escherichia coli, Salmonella spp. in Staphylococcus aureus, in ki jih enostavno kvantificiramo s preprosto kultivacijsko metodologijo. Relativno višje število bakterij na RIDA ${ }^{\circ} \mathrm{COUNT}$-ovih testnih ploščah $\mathrm{v}$ primerjavi $\mathrm{s}$ kvasovkami in plesnimi nakazuje nedaven in poudarjen človekov vpliv. Vzorci brisov površin $\mathrm{v}$ jamah omogočajo detekcijo gradientov mikrobne kolonizacije površin in določanje mikrobne obremenjenosti odtisov stopal in prstov. $\mathrm{V}$ naši raziskavi smo z RIDA ${ }^{\circ} \mathrm{COUNT}$-ovimi ploščami za določanje celokupnega števila kvasovk in plesni pokazali podobno mikrobno obremenjenost površin neumitih jamarskih škornjev in prstnih odtisov na kovinski ograji. Podobno je bilo tudi celokupno število bakterij med obema površinama, kar pomeni $5.890 \mathrm{CFU} / 100 \mathrm{~cm}^{2}$ za neumite škornje oziroma $4.340 \mathrm{CFU} / 100 \mathrm{~cm}^{2}$ za odtise prstov na kovinski ograji. Število bakterij na pohodnih površinah v urejenih turističnih jamah lahko preseže $10.000 \mathrm{CFU} / 100 \mathrm{~cm}^{2}$ (Postojnska jama). Predstavljeni primeri kažejo, da je kvantificiranje mikrobnih indikatorskih skupin pokazalo povišano mikrobno obremenjenost in morebitno biološko tveganje $\mathrm{v}$ podzemlju. Predstavljen postopek se lahko uporablja tudi širše kot del rednega monotoringa $\mathrm{v}$ jamah.

Ključne besede: jame, mikroorganizmi, monitoring, človekov vpliv, kvaliteta vode.

\footnotetext{
${ }^{1}$ Karst Research Institute, Research Centre of the Slovenian Academy of Sciences and Arts, Titov trg 2, 6230 Postojna, Slovenia, e-mail: janez.mulec@guest.arnes.si

${ }^{2}$ Biology Centre, Academy of Sciences of the Czech Republic, v.v.i. - Institute of Soil Biology, Na Sádkách 7, 37005 České Budějovice, Czech Republic, e-mail: kristuf@upb.cas.cz, alicach@upb.cas.cz
}

Received/Prejeto: 12.03 .2012 


\section{INTRODUCTION}

Karst caves are peculiar habitats inhabited by different microorganisms adapted to oligotrophic conditions. Therefore, oligotrophic caves are primarily dominated by autochtonous microbiota (Northup \& Lavoie 2001). Microorganisms in different karst systems represent a significant source of nutrients (e.g. Lukešová \& Frouz 2007; Lukešová \& Nováková 2009; Mulec 2008; Paolletti et al. 2011; Summers Engel 2012a, b; Šustr et al. 2005) and contribute to geochemical processes in caves, such as speleothem formation, rock weathering and carbon sequestration. There is strong evidence of the importance of climate change as an agent forcing or isolating organisms in subterranean habitats (Culver \& Pipan 2010). On the other hand, colonization of caves by allochtonous microorganisms due to increased microbial pollution can be a critical point in the protection of karst ecosystems (Lavoie \& Northup 2006; Northup 2009). Some cave niches, such as water-filled cave ponds rich in organic matter in subtropical and tropical areas can become reservoirs of human pathogens (unpublished data), which merits further attention in recent times, when human impact on subsurface karst habitats is very pronounced. Therefore, cave microbiota face organic pollution and invasion of new microbes. Invading species, especially pathogens, are usually dependent on increased organic carbon availability, and after organic matter depletion their populations usually diminish (van Elsas et al. 2012). In contrast to other groups of microorganisms, humanassociated microbes are easily detected with currently existing methodology that focuses on detection of clinically important groups or species (Escherichia coli, Salmonella spp., Staphylococcus aureus, etc.). In the last few decades a vast variety of new techniques and methods have been developed to study microorganisms, many of which do not rely on cultivation of microbial cultures (e.g. Campbell et al. 1997; Dubois et al. 2004; Kirk et al. 2004; Liu et al. 1997; Malik et al. 2008; Moter \& Gobel 2000; Nocker et al. 2007; Ronaghi 2001; Tiedje et al. 1999). Depending on the purpose, well-established cultivation media and protocols often provide fast, reliable, low-cost and reproducible results (e.g. Nichols 2007; Ritz 2007). Application of this classical approach in caves is usually time consuming and transport demanding. Estimation of microbial loads in cave habitats supplements data on general health of the underground environment, microbial pollution, and especially water quality assessment. Here we review a procedure which has been previously applied in the karst underground (Mulec et al. 2012) and has been used for several years for routine monitoring in Slovenia and Slovakia with special emphasis on introduc- tion of microorganisms into caves via different human activities.

This procedure resulted from a request by cave management to develop, for a reasonable price, a regular monitoring procedure based on established microbial indicator groups, to evaluate microbiological pollution due to tourist presence and activities, to report the status of underground habitats, and to establish measures to preserve the cave environment. From this point cave ecologists are further interested in distinguishing these microbial invaders from naturally occurring cave biota, determining the significance of various levels of abundance in caves, and learning how to direct more complex environmental studies based upon initial microbial screening.

In this paper, we present and discuss advantages and disadvantages of a method based on one ready-touse medium plate system, RIDA ${ }^{\circledR}$ COUNT test plates (RBiopharm 2012). We discuss considerations associated with the selection of sampling and monitoring sites as well as evaluation and interpretation of data. Examples of monitoring procedures, sites and applications are also provided. The steps described below are applicable for caves, or parts of caves, which are subjected to high organic loads, and can be considered one of the first steps prior to applying more sophisticated methods, especially in caves which are being visited for the first time.

Three different types of samples can be taken in caves, corresponding to three different types of habitats that are colonized by heterotrophic microorganisms: air, swabs of solid surfaces and water. To activate the media, $1 \mathrm{ml}$ of sterile physiological saline must be applied to plates before sampling of air and swabs, preferably before caving. Alternatively, if we run out of such pre-prepared plates, they can be prepared directly on the spot by spreading the sterile physiological saline $(0.9 \% \mathrm{NaCl})$ from purchased one millilitre ampoules (R-Biopharm, Germany). A depositional sedimentation method and/or impacting can be adopted to sample airborne microorganisms by RIDA ${ }^{\oplus}$ COUNT test plates. Paperclips may be used to hold plates open and exposed to the cave atmosphere for different periods of time; however we suggest that 20 minutes is enough to get an idea of the culturability of airborne microbes (Fig. 1). It is important to obtain the "background" of cave airborne microbiota and to do sampling before the rest of the expedition group enters the cave. In contrast to the depositional sedimentation method, impacting is more precise and quantitative; application of $\mathrm{RIDA}^{\oplus} \mathrm{COUNT}$ test plates to automated air sampling, for example with a Mas-100 (Merck, Germany), is simple as well (Mulec et al. 2012b). 
One of the major advantages of RIDA ${ }^{\circ} \mathrm{COUNT}$ test plates is very easy sampling of swabs because the plates are flexible and can allow direct swabbing of surfaces

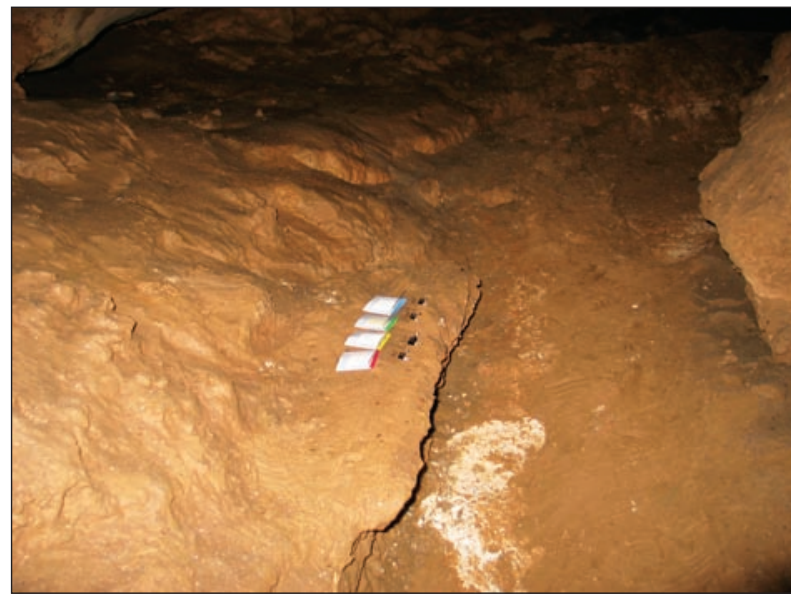

Fig. 1: Sampling of airborne microorganisms. A depositional sedimentation method in Bobačka Cave, Slovakia, 9 May 2011 (Photo: Janez Mulec). with plates. A $20-\mathrm{cm}^{2}$ surface with minimum irregularities can be sampled very simply, and various types of surfaces are not limiting for sampling. Each solid surface represents a feasible microhabitat for microbial colonization. The variety of surfaces that may be swabbed in caves is huge: pristine rocky surfaces, cave allochtonous materials, surfaces covered with different organic layers and, especially in show caves, surfaces experiencing tourist visits such as footprints and fingerprints.

Water samples can be also easily applied onto the medium sheets. Medium must be aseptically inoculated with $1 \mathrm{ml}$ of water specimen. To avoid carrying microbiological samples in cool boxes and for later inoculation in a lab, the simplest way is to use single-use sterile Pasteur pipettes and apply $1 \mathrm{ml}$ of samples directly onto plates in the cave. Once colonies have formed on RIDA ${ }^{\circ} \mathrm{COUNT}$ plates, their recovery onto classical microbiological media in order to perform further strain characterization is very straightforward.

\section{MATERIALS AND METHODS}

\section{DESCRIPTION OF STUDIED CAVES}

One cave in Slovenia (Postojna Cave, sampled from 2426 June 2010) and five caves in Slovakia including Ardovská Cave (Ardovská jaskyňa, National Park Slovak Karst), Bobačka Cave (jaskyňa Bobačka, NP Muran Plateau), Demänovská Cave of Peace (Demänovská jaskyňa Mieru, NP Low Tatras), Demänovská Cave of Liberty (Demänovská jaskyňa Slobody, NP Low Tatras), and Dead Bats Cave (Jaskyňa mŕtvych netopierov, NP Low Tatras) were studied. Slovak caves were sampled from 9-12 May 2011. Background on the caves is summarized in Tab. 1. Postojna Cave (Postojnska jama) is part of the second longest cave system in Slovenia, Postojna-Planina Cave System (with a total length of $20.57 \mathrm{~km}$ ) containing the underground Pivka River, and is partially developed for tourist visits. This show cave is visited by approximately 500,000 tourists per year. Ardovská Cave, Bobačka Cave, and Demänovská Cave of Peace are not open to the public. Demänovská Cave of Liberty is part of the longest cave system in Slovakia, Demänovský Cave System, $(35.29$ km long). Demänovská Cave of Liberty is a show cave, and it is visited by 180,000 tourists per year. Dead Bats Cave is partly a show cave but with a very limited number of visitors per year. All caves except Postojna Cave have roosting bat colonies, and only in Ardovská Cave is there no active underground stream. All studied caves are gated.

\section{DESCRIPTION OF MEDIA}

Research in the underground is often limited by the physical ability to transport material in addition to the necessary special equipment for caving and safety. Having this in mind we successfully applied one microbiological kit that can be used even during a difficult caving expedition, RIDA ${ }^{\circ} \mathrm{COUNT}$ test plates (R-Biopharm 2012). This kit has already been used for different purposes in caves of Slovenia and Slovakia (Mulec et al. 2012a), and in China (Knez et al. 2012), Romania, and Cuba (unpublished data). The RIDA ${ }^{\circ} \mathrm{COUNT}$ test plates, which contain a specific chromogenic detection system, successfully substitute for classical microbiological media in Petri dishes. RIDA $^{\circ}$ COUNT is made of a base film coated with a dry culture medium and covered by a fabric, which allows absorbance of the applied sample solution $(1 \mathrm{ml})$. The correlation between plate count agar and Petrifilm is satisfactory (Morita et al. 2003, 2006). The complete list of available media is available on-line (R-Biopharm 2012); however in caves we successfully used the kits for total counts of heterotrophic aerobic bacteria (RIDA ${ }^{\circ} \mathrm{COUNT}$ Total Aerobic Count), conventional total coliform bacteria (RIDA ${ }^{\circ}$ COUNT Coliform), Escherichia coli/coliforms (RIDA ${ }^{\circ}$ COUNT E. coli/Coliform), Staphylococcus aureus (RIDA ${ }^{\circ} \mathrm{COUNT}$ Staph. aureus), enterobacteria and Salmonella (RIDA ${ }^{\circ} \mathrm{COUNT}$ Salmonella/Enterobac- 
Tab. 1: Location and characterization of the caves in this study (all are gated).

\begin{tabular}{|c|c|c|c|c|c|c|c|c|c|}
\hline Cave & $\begin{array}{l}\text { Geographic } \\
\text { coordinates }^{a}\end{array}$ & $\begin{array}{l}\text { Altitude } \\
{\text { (m a.s.l. })^{a}}\end{array}$ & $\begin{array}{l}\text { Length } \\
(m)^{a}\end{array}$ & $\begin{array}{l}\text { Air temperature } \\
\left({ }^{\circ} \mathrm{C}\right)\end{array}$ & $\begin{array}{l}\text { Relative } \\
\text { humidity (\%) }\end{array}$ & $\begin{array}{l}\text { Underground } \\
\text { stream }\end{array}$ & Plant cover & $\begin{array}{l}\text { Number of } \\
\text { bats }^{a}\end{array}$ & $\begin{array}{l}\text { Visitors per } \\
\text { year }^{a}\end{array}$ \\
\hline Ardovská Cave & $\begin{array}{l}48^{\circ} 52^{\prime} 14^{\prime \prime} \mathrm{N} \\
20^{\circ} 42^{\prime} 09^{\prime \prime} \mathrm{E}\end{array}$ & 314 & 1,492 & $8.0-11.5$ & 97.8 & No & $\begin{array}{l}\text { Deciduous } \\
\text { forest, shrubs }\end{array}$ & Max. 200 & Wild cave ${ }^{b}$ \\
\hline Bobačka Cave & $\begin{array}{l}48^{\circ} 46^{\prime} 56^{\prime \prime} \mathrm{N}, \\
20^{\circ} 6^{\prime} 20^{\prime \prime} \mathrm{E}\end{array}$ & 680 & 3,036 & $8.1-9.9$ & $90.0-100.0$ & Yes & $\begin{array}{l}\text { Beech with } \\
\text { incidental } \\
\text { spruce }\end{array}$ & 160 & Wild cave ${ }^{b}$ \\
\hline Dead Bats Cave & $\begin{array}{l}48^{\circ} 55^{\prime} 30^{\prime \prime} \mathrm{N}, \\
19^{\circ} 38^{\prime} 20^{\prime \prime} \mathrm{E}\end{array}$ & 1,510 & 19,260 & $3.6-5.4$ & $98.3-100.0$ & Yes & $\begin{array}{l}\text { Mountain } \\
\text { meadow with } \\
\text { scrubs }\end{array}$ & No data & 2,125 \\
\hline $\begin{array}{l}\text { Demänovská Cave of } \\
\text { Liberty }\end{array}$ & $\begin{array}{l}48^{\circ} 59^{\prime} 53^{\prime \prime N}, \\
19^{\circ} 35^{\prime} 8^{\prime \prime} \mathrm{E}\end{array}$ & 870 & 8,497 & $7.4-9.4$ & $91.5-100.0$ & Yes & Spruce & 2 & 181,000 \\
\hline $\begin{array}{l}\text { Demänovská Cave } \\
\text { of Peace }\end{array}$ & $\begin{array}{l}49^{\circ} 0^{\prime} 7 " \mathrm{~N}, \\
19^{\circ} 34^{\prime} 58^{\prime \prime} \mathrm{E}\end{array}$ & 812 & 16,245 & $7.1-9.1$ & $90.2-100.0$ & Yes & Spruce & 0 & Wild cave $^{b}$ \\
\hline Postojna Cave & $\begin{array}{l}45^{\circ} 47^{\prime} 0.43^{\prime \prime} \mathrm{N}, \\
14^{\circ} 12^{\prime} 10.09^{\prime \prime} \mathrm{E}\end{array}$ & 529 & 20,570 & $10.5-13.2$ & $88.3-100.0$ & Yes & $\begin{array}{l}\text { Deciduous } \\
\text { forest, shrubs }\end{array}$ & Transitory & 500,000 \\
\hline
\end{tabular}

${ }^{a}$ Data according Slovak Caves Administration (Liptovský Mikuláš, Slovakia), Bella et al. (2007), Hapl et al. (2002), Núdziková (2009), Núdziková \& Gaál (2011), Uhrin et al. (2002), Višňovská (2007) and Cave Cadastre of the Karst Research Institute at ZRC SAZU and the Speleological Association of Slovenia

${ }^{\mathrm{b}}$ Occasionally visited by speleologists and/or archeologists

teriaceae), and counts of culturable yeasts and moulds (RIDA ${ }^{\circ}$ COUNT Yeast\&Mold Rapid).

\section{TYPES OF SAMPLES AND MANIPULATION}

In caves three different types of habitats can be sampled: air, solid surfaces and water. Here we present examples of air and surface swab samples from selected Slovenian and Slovak caves (Tab. 1). RIDA ${ }^{\circ}$ COUNT test plates have media surfaces of $20 \mathrm{~cm}^{2}$, making reporting of results simple. All plates were moistened and activated by adding $1 \mathrm{ml}$ of sterile physiological saline $(0.9 \% \mathrm{NaCl})$.

Airborne microorganisms were sampled using a depositional method in which RIDA ${ }^{\circ}$ COUNT test plates were exposed to cave atmosphere for 20 minutes. Sampling sites were carefully selected prior to caving and a maximum of five members of the research team were present at the moment of sampling.

There are many different surfaces that may be swabbed in caves. Due to high variability of surfaces and limited availability of space at certain sites, many times it is impossible to swab multiple replicates. In this study, we sampled different surfaces that may directly indicate human impact in the underground. Prior to caving by 11 speleobiologists from our research team we swabbed their hairs, skin, washed and unwashed boots, and during caving we swabbed foot- and fingerprints. Swabbing of footprints from the caving path was conducted in Bobačka Cave immediately after the group of speleolobiogists passed. To compare these data with surfaces affected by tourist visits we sampled the tourist path at several sites in Postojna Cave 30 minutes after a group of tourists had passed. Alternatively, cave surfaces can reflect high organic loads not directly associated with human presence. To demonstrate this we sampled bedrock with an organic layer presumably originating from bat guano, a surface affected by unidentified animal excrement deep in a cave, and a sediment surface regularly flooded by the organically polluted underground river.

\section{READING RESULTS}

After plate inoculation in caves, test plates should be placed in an incubator (e.g. CULTURA ${ }^{\oplus}$ Mini-Incubator, R-Biopharm, Germany, temperature range $25-45^{\circ} \mathrm{C}$ ) as soon as possible for an appropriate time. We recommend prolonging cultivation for an additional twentyfour hours (Mulec et al. 2012a), as is also suggested by the producer. An additional incubation period revealed higher microbial counts and probably gives a more realistic view of the microbial communities, because some cave microbes have demonstrated slow growth on selected RIDA ${ }^{\circ}$ COUNT media (Mulec et al. 2012a). Cultivation periods should be clearly reported. The kit was originally designed for monitoring of hygiene indicators in food processing and raw materials, which likely have higher growth rates than do cave microbes. Microbial counts are expressed as colony-forming units (CFU) per $100 \mathrm{~cm}^{2}$ for swabs, CFU $/ 20 \mathrm{~cm}^{2} / 20 \mathrm{~min}$ or $\mathrm{CFU} / \mathrm{m}^{3}$ for airborne microbiota obtained by the sedimentation method or impacting, respectively, and as $\mathrm{CFU} / \mathrm{ml}$ or CFU/100 ml for water samples. 


\section{RESULTS AND DISCUSSION}

\section{EVALUATION}

To report results, data must be compared with standardized values. For water samples, this process is straightforward. In order to use water from a cave for consumption, it must meet the following criteria based on ISO standards in the section ICS 13.060 for drinking water (ISO 2012): the number of coliforms must not exceed 0 CFU in a $100 \mathrm{ml}$ sample of water (SIST EN ISO 9308-1), and the total number of mesophilic bacteria at $37^{\circ} \mathrm{C}$ must be under $100 \mathrm{CFU}$ per ml (SIST EN ISO 6222). Applying concentrated water samples to RIDA ${ }^{\circ} \mathrm{COUNT}$ test plates is simple. For example, $100 \mathrm{ml}$ of water is filtered through a $0.22-\mu \mathrm{m}$ pore size sterile filter $(0.47 \mathrm{~mm}$ in diameter). The filter is then placed on the selected RIDA ${ }^{\circ}$ COUNT medium, which has been previously activated by adding one $\mathrm{ml}$ of sterile physiological saline. At the end of the cultivation period, coloured colonies on the filter are simply expressed as CFU per $100 \mathrm{ml}$.

Concentrations of microbiota in the cave air can be compared to guidelines for residential rooms (Verhoeff 1993). Although caves cannot be simply treated as living environments for humans, these estimates can be used as a reference for caves or other artificial cavities that are used for speleotherapy. Nevertheless, more data are needed to get an idea of how many culturable microbiota in different caves result from human activities and how many can be expected in a pristine underground environment. Here we give an example of concentration

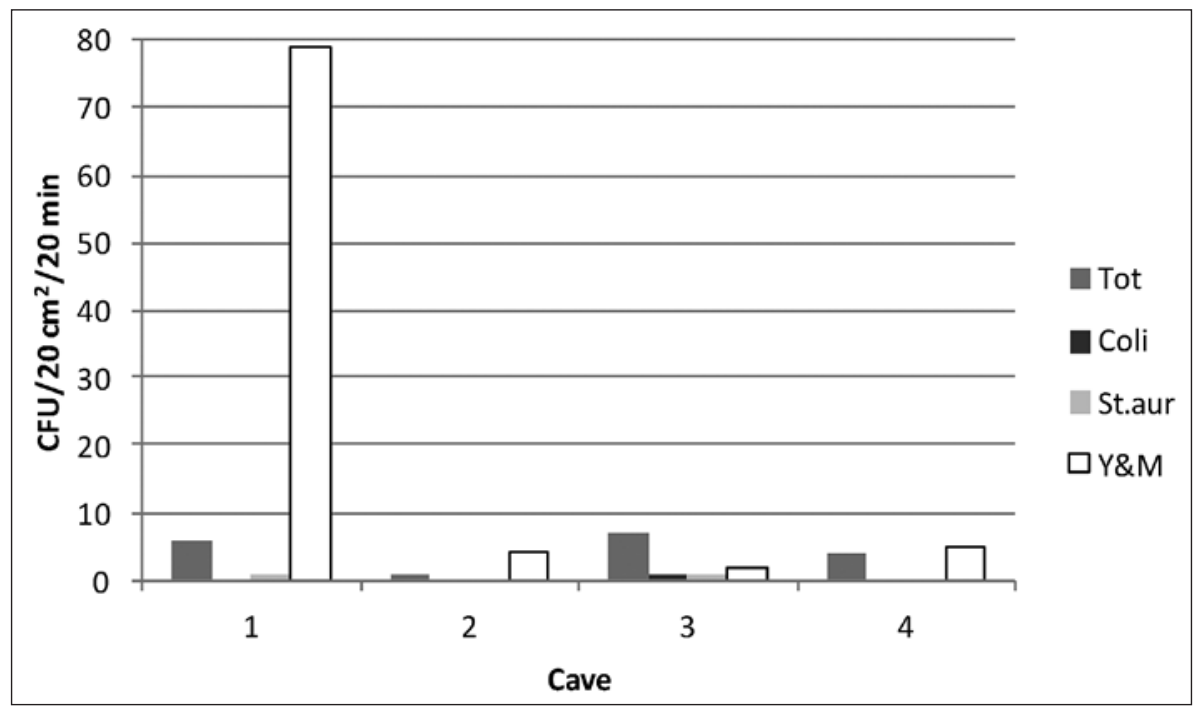

Fig. 2: Average values of culturable bacteria after $48 \mathrm{hrs}$ of cultivation at $35^{\circ} \mathrm{C}$ (Tot-total bacterial counts, Coli-total counts of coliforms, St.aur-count of Staphylococcus aureus) and yeast and mould counts after 72 hours of cultivation at $25^{\circ} \mathrm{C}(Y \& M)$ in the air on the exposed surface of $20-\mathrm{cm}^{2}$ open RIDA ${ }^{\circ}$ COUNT plates for 20 minutes in individual cave systems (1-Bobačka Cave, 2- Demänovská Cave of Peace, 3- Demänovská Cave of Liberty, 4-Dead Bats Cave, all in Slovakia). of airborne microorganisms from four Slovakian caves: Bobačka Cave, Demänovská Cave of Peace, Demänovská Cave of Liberty, and Dead Bats Cave (Fig. 2). Elevated numbers of yeast and moulds were detected in Bobačka Cave compared to the other caves, which can be attributed to higher organic load in this cave compared to the other caves. The wild part of Demänovská Cave of Peace had on average low concentrations of airborne microorganisms. In Demänovská Cave of Liberty air was sampled in the touristic part of the cave; this is why the bacterial counts were higher than yeast and moulds. Higher bacterial counts compared to yeast and moulds on $\mathrm{RIDA}^{\circ} \mathrm{COUNT}$ test plates indicated pronounced human impact. In this part of the cave, coliform bacteria were also detected in the air, which is not necessarily linked to human activities, because coliforms are widespread in nature. A similar range of microbial load in the air was observed in the wild areas of Demänovská Cave of Peace and Dead Bats Cave. No beta-haemolytic Staphylococcus aureus were detected in cave air (Fig. 2).

The analysis of swabs collected in caves can be very complex. The above-mentioned RIDA ${ }^{\circ}$ COUNT media support growth of heterotrophic species that do not demand special media or growth conditions. Different swabs can have similar or different numbers of culturable microorganisms per surface unit. Here we report the concentrations of microbial loads on surfaces, which can indicate human impact in caves: human hairs, skin, boots washed prior to caving, unwashed boots, a footprint in a cave, footprints of 11 people in a cave, an untouched fence in Demänovská Cave of Liberty (show cave) and the same fence touched by 11 people (Fig. 3).

Cavers bring a lot of cultivable microorganisms on their boots into caves (Fig. 3). Special attention should be paid to those caves with naturally low organic input. A distinct difference (3-fold) based on total bacterial counts can be observed between a footprint of one person (No. 5) and footprints of 11 people inside the cave (No. 6). Another important anthropogenic input in the cave represents surfaces 


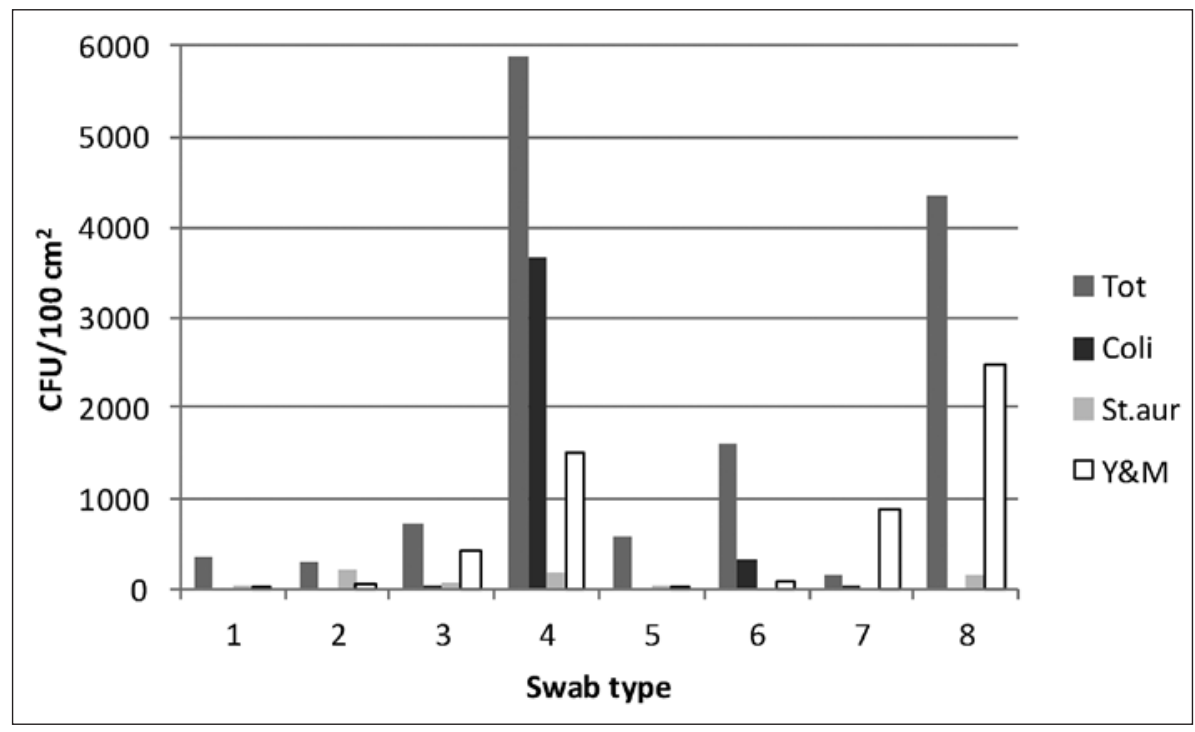

Fig. 3: Average values calculated as colony-forming units (CFU) per $100 \mathrm{~cm}^{2}$ of swabs taken prior to caving (1-hairs, 2-skin, 3-boots washed, 4-boots unwashed) and in a cave (5-footprint in cave, 6-footprints of 11 people in cave, 7-fence untouched, 8-fence touched by 11 cave tourists), for bacterial counts after $48 \mathrm{hrs}$ of cultivation at $35^{\circ} \mathrm{C}$ (Tot-total bacterial counts, Coli-total counts of coliforms, St.aur-count of Staphylococcus aureus) and for yeast and mould counts after 72 hours of cultivation at $25^{\circ} \mathrm{C}(\mathrm{\mho} \leftrightarrow M)$.

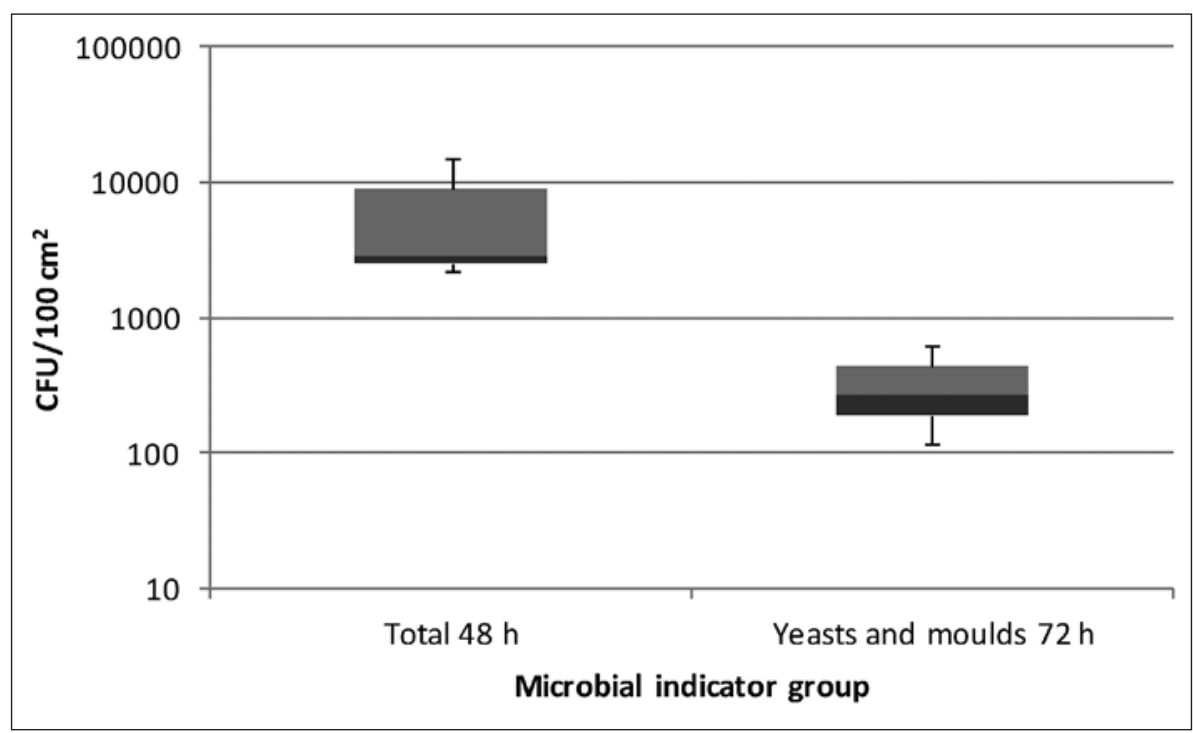

Fig. 4: Analyses of swabs from tourist pathways collected after tourist visits in Postojna Cave (Slovenia). Stacked columns on logarithmic scale represent minimum and maximum counts of microbes and CFU values in first, second and third quartile after cultivation at $35^{\circ} \mathrm{C}$ for 48 hours for total aerobic bacteria (Total $48 \mathrm{~h}$ ) and after 72 hours of cultivation at $25^{\circ} \mathrm{C}$ for yeasts and molds (Yeast \& Molds $72 \mathrm{~h}$ ).

which have come into direct contact with human skin. A distinct difference in microbial counts was observed between untouched (No. 7) and touched tourist fences (No. 8). Footprints and fingerprints represent a significant anthropogenic input into the cave; interestingly RIDA $^{\circ}$ COUNT for yeast and moulds revealed similar microbial loads between unwashed boots and fingerprints on a metal fence. Total bacterial counts were in a similar range, 5,890 $\mathrm{CFU} / 100 \mathrm{~cm}^{2}$ for unwashed boots and $4,340 \mathrm{CFU} / 100 \mathrm{~cm}^{2}$ for fingerprints on the metal fence. No beta-haemolytic S. aureus with characteristic black colonies with a blue halo were detected (Fig. 3). The microbial load on walking surfaces in show caves is even more pronounced, where bacterial counts can exceed 10,000 CFU/100 $\mathrm{cm}^{2}$ (Fig. 4). Recent human impact, such as a visit in caves, is correlated with relatively increased bacterial counts compared to yeast and mould counts when using RIDA $^{\circ} \mathrm{COUNT}$ test plates.

Swabs are good indicators to show a gradient of microbial colonization. Therefore, comparison of surfaces from tourist paths with other surfaces that less frequently encounter human contact must be very carefully interpreted. There are many surfaces in caves with high microbial load that are not directly linked to human activities (Fig. 5).

When comparing microbial load of different swabs, a logarithmic scale is recommended by the APHA (American Public Health Association) and HACCP (Hazard Analysis Critical Control Point) (Gavron \& Luck 1990). To analyse cave swabs, a similar scale has been proposed: numbers $\leq 100$ total CFU $/ 100 \mathrm{~cm}^{2}$ represent low levels of microbially colonized surfaces, $101-1,000 \mathrm{CFU} / 100 \mathrm{~cm}^{2}$ represent low-medium, $1001-10,000 \mathrm{CFU} / 100 \mathrm{~cm}^{2}$ represent medium, and $\geq 10,001 \mathrm{CFU} / 100 \mathrm{~cm}^{2}$ represent high levels of surface colonization by microbes (Mulec et al. 2012a). 


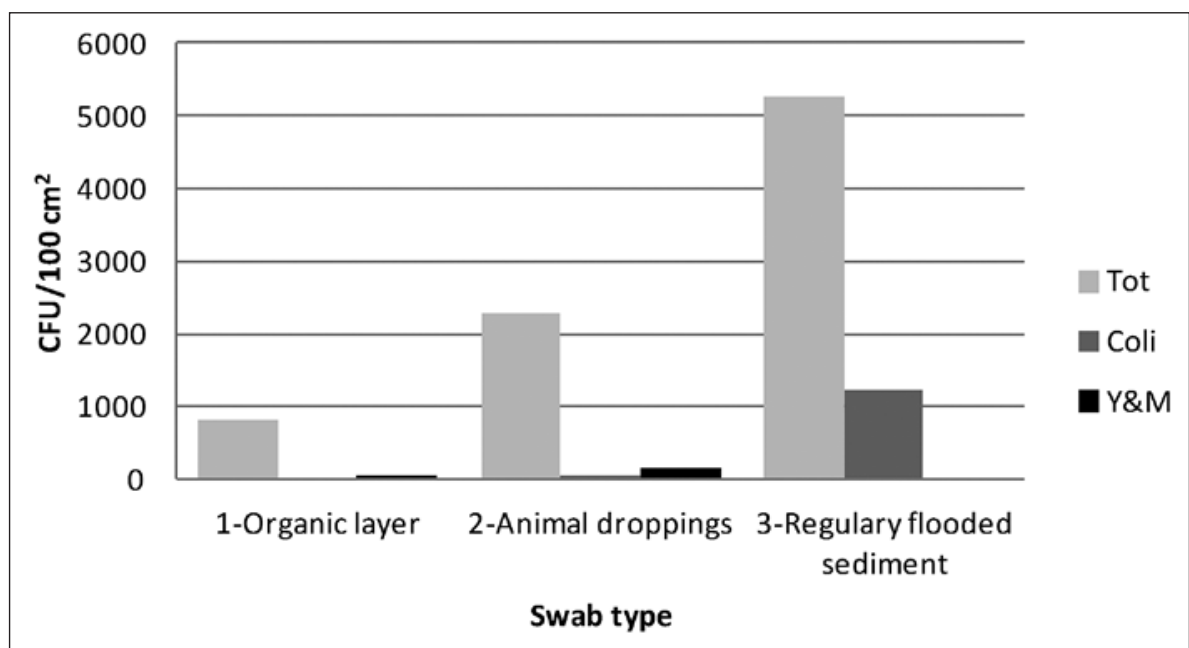

Fig. 5: Microbial load on cave surfaces expressed as CFU per $100 \mathrm{~cm}^{2}$ : 1-bedrock with organic layer, 2-speleothem with unidentified animal excrement, both from Ardovská Cave (Slovakia), and 3-sediment from Postojna Cave in an area regulary flooded by the underground Pivka river (Postojnska jama, Slovenia).

\section{PROBLEMS AND CONSIDERATIONS}

The most important issue when using cultivation techniques is selection of appropriate media. Generally only about $1-10 \%$ of soil microorganisms can be cultured (Davis et al. 2005; Torsvik et al. 1998; van Elsas et al. 2006). Commercially available nutrient-rich media give a good support for fast-growing, generally easily isolatable/cultivable species. Incubation conditions, such as temperature, can be adjusted as well, but if we attempt to monitor recent human impact on the underground, the recommended temperature $\left(35-37^{\circ} \mathrm{C}\right)$ corresponds to the body temperature of the major vector and may give satisfactory results.

When planning to establish monitoring stations for sampling swabs, the selection of representative sites must be taken into account. Selected monitoring sites should have a smooth surface and should allow simple and frequent access. This is important in caves with mass tourism when we monitor introduction of culturable microbes by tourists. Lower numbers of detected colonies are not necessarily linked with low organic input. A slight change of swab location might give false results. In such cases, increased numbers of replicates and labelling of monitoring sites are recommended to overcome the problem of reproducibility. A similar problem occurs when sampling of airborne microorganisms is performed by the sedimentation method. One has to take

Tab. 2: Examples of monitoring in karst caves using microbial indicator groups with strengths and weaknesses.

\begin{tabular}{l|l|l|l|l}
\hline Type & $\begin{array}{l}\text { Microbial indicator } \\
\text { group* }\end{array}$ & $\begin{array}{l}\text { Example for } \\
\text { underground use }\end{array}$ & Strengths & Weaknesses \\
\hline Air & total aerobic count & $\begin{array}{l}\text { speleotherapy } \\
\text { stations } \\
\text { yeast and molds }\end{array}$ & $\begin{array}{l}\text { easy manipulation } \\
\text { organic loads- } \\
\text { biohazards } \\
\text { easy tuning of different exposure times } \\
\text { of open plates } \\
\text { quantifiable with time or volume }\end{array}$ & $\begin{array}{l}\text { a single colony might represent } \\
\text { large microbial cluster on a } \\
\text { dust particle } \\
\text { repeatability }\end{array}$ \\
\hline Swab & $\begin{array}{l}\text { total aerobic count } \\
\text { interpretation }\end{array}$ \\
$\begin{array}{l}\text { Staphylococcus aureus } \\
\text { Salmonella/ } \\
\text { Enterobacteriaceae } \\
\text { yeast and molds }\end{array}$ & $\begin{array}{l}\text { show caves, to } \\
\text { monitor quantity } \\
\text { of introduced } \\
\text { microbes on foot- } \\
\text { and fingerprints }\end{array}$ & $\begin{array}{l}\text { microbial quantification } \\
\text { gradient monitoring of microbial load } \\
\text { determination of microbial source }\end{array}$ & $\begin{array}{l}\text { quantifiable with sampling of a } \\
\text { in caves } \\
\text { standardized areas }\end{array}$ & $\begin{array}{l}\text { caution required in } \\
\text { interpretation }\end{array}$ \\
\hline Water & $\begin{array}{l}\text { total aerobic count } \\
\text { E.coli/coliform } \\
\text { Salmonella/ } \\
\text { Enterobacteriaceae }\end{array}$ & $\begin{array}{l}\text { caves with } \\
\text { underground river } \\
\text { flow } \\
\text { spring caves for } \\
\text { drinking water }\end{array}$ & $\begin{array}{l}\text { microbial quantification } \\
\text { on-site inoculation } \\
\text { easy interpretation } \\
\text { quantifiable with volume } \\
\text { repeatability }\end{array}$ & $\begin{array}{l}\text { occasional need to concentrate/ } \\
\text { dilute samples }\end{array}$ \\
\hline
\end{tabular}


into consideration that the influence and activities of humans and animals in caves are mostly random and heterogeneous. Moreover, other important factors influencing microbial counts are cave climate and air movements. Although different media specific for certain microbial groups are now available, this cultivation method might fail in caves with low organic input or with in situ primary production, because of insufficient sensitivity and/ or inappropriate cultivation media.

$\mathrm{RIDA}^{\circledR} \mathrm{COUNT}$ test plates have already been successfully applied in many caves worldwide after a request by cave managers to use microbial indicators to monitor health of the underground environment (Tab. 2). Easy and simple handling with $\mathrm{RIDA}^{\circledR} \mathrm{COUNT}$ test plates gives opportunities for studying new cave micro-niches and influence of various gradients on enumeration of aerobic heterotrophic microorganisms. Colonies grown on these plates can be further processed on other microbiological media and characterized by biochemical tests, serotyping or other molecular tools.

\section{CONCLUSIONS}

Microbial enumeration in different cave environments has by itself limited value for determining the status of underground habitats, and similar can be said for sampling only once in a particular cave. Microbiological data should be supplemented with other physical and chemical measurements of atmosphere, water bodies, and cave use. However, microbiological data do offer important information, especially for eutrophic caves. Detection of putative human pathogens, such as E. coli, Salmonella spp. or $S$. aureus, in samples should be taken into serious consideration as these are potential biohazard agents. Further identification is required to properly characterize these isolates. If we suspect the presence of $E$. coli, for example, in underground water, "false" negative results should be further examined, for instance by concentrating the sample. Sources of these allochtonous microbes in the underground should be located, and especially if they originate from human activities, these activities should be suspended.

Commercial kits such as the one described here are easy to use, allow sampling of many sites, and are eas- ily transported by researchers and/or the accompanying team. For these reasons, they allow flexibility, replication and multiple sampling of many sites in caves. They represent a suitable, reasonable, and cost-effective tool for cave microbiologists as an alternative method to classical plate count agar. These techniques enable quick insight into microbial loads and biohazards in the underground and can be adopted as a part of a routine monitoring programme in caves. The number of existing specialized kits may be tested for suitability before starting a comprehensive and time-consuming search for the most specific and sensitive cultivation conditions. This supplementary tool can help researchers to choose the most suitable microhabitats for monitoring and more detailed future study. Easy manipulation and reading of results as well as the robustness of such kits may enable their wider use in sensitive underground habitats. Such kits can also be used by non-specialists, so long as there is recognition that microbial colonies represent potential hazards and should be properly disposed.

\section{ACKNOWLEDGEMENTS}

The study was supported by the Research Programme P6-0119 "Karst Research", monitoring plan of Postojna Cave, Slovenia: "Expert control and recommendations for management of cave systems" and "Climatic and biologic monitoring of cave systems", L6-2156 Monitoring and analysis of selected climatic parameters in karst caves: The case of Postojna cave system, IGCP-UNESCO project no. 598 "Environmental change and sustainability in karst systems”, MEYS CR (No. LC06066), operation Program-Life Habitat (No. 241501120041) and an interacademic exchange programme between the Czech Academy of Science and Slovenian Academy of Sciences and Arts. Authors are grateful to Elizabeth D. Covington for language assistance. 


\section{REFERENCES}

Bella, P., Hlaváčová, I. \& P. Holúbek, 2007: List of Caves of the Slovak Republic (until 30/6/2007).- The Slovak Museum of Nature Protection and Speleology, pp. 364, Liptovský Mikuláš. [In Slovak]

Campbell, C.D., Grayston, C.J. \& D.J. Hirst, 1997: Use of rhizosphere carbon sources in sole carbon tests to soil microbial communities.- Journal of Microbiological Methods, 30, 1, 33-41.

Culver, D.C. \& T. Pipan, 2010: Climate, abiotic factors, and the evolution of subterranean life.- Acta Carsologica, 39, 3, 577-586.

Davis, K.E.R., Joseph, S.J. \& P.H. Jansen, 2005: Effects of growth medium, inoculum size and incubation on culturability and isolation of soil bacteria.- Applied and Environmental Microbiology, 71, 2, 826-834.

Dubois, G.W., Hill, S., England, L.S., Edge, T., Masson, L., Trevors, J.T. \& E. Brousseau, 2004: The development of a DNA microarray-based assay for the characterization of commercially formulated microbial products.- Journal of Microbiological Methods, 58, 2, 251-262.

Gavron, H. \& H. Luck, 1990: Quality control in dairy industry.- In: Robinson, R.K (ed.) Dairy Microbiology. Vol. 2, Chapman \& Hall, pp. 345-392, London.

Hapl, E., Uhrin, M., Bobáková, L., Benda, P., Andreas, M., Reiter, A., Hotový, J., Obuch, J., Stankovič, J. \& K. Cselényi, 2002: Overview of wintering bats in Silická and Plešivecká plains.- Vespertilio, 6, 193-211. [In Slovak with English abstract]

ISO, 2012: International organization for standardization.- [Online] Available from: http://www.iso.org [Accessed 13 $3^{\text {th }}$ May 2012].

Kirk, J.L., Beaudette, L.A., Hart, M., Moutoglis, P., Klironomos, J.M., Lee, H. \& J.T. Trevors, 2004: Methods of studying soil microbial diversity.- Journal of Microbiological Methods, 58, 2, 169-188.

Knez, M., Kogovšek, J., Liu, H., Mulec, J., Petrič, M., Ravbar, N. \& T. Slabe, 2012: Karstological study of the new Kunming airport building area (Yunnan, China).- Environmental Earth Sciences, 67, 1, 273283.

Lavoie, K.H. \& D.E. Northup, 2006: Bacteria as indicators of human impact in caves.- In: Rea, G.T. (ed) Proceeding of the $17^{\text {th }}$ National Cave and Karst Management Symposium, NICKMS steering Committee, $31^{\text {st }}$ October- $4^{\text {th }}$ November 2005, Albany, National Cave \& Karst Management Symposium, 40-47, Albany, NY.
Liu, W.T., Marsh, T.L., Cheng, H. \& L.J. Forney, 1997: Characterization of microbial diversity by determining terminal restriction fragment length polymorphisms of genes encoding 16S rRNA.- Applied and Environmental Microbiology, 63, 11, 45164522.

Lukešová, A. \& J. Frouz, 2007: Soil and freshwater microalgae as a food source for invertebrates in extreme environments.- In: Seckbach, J. (ed.) Algae and Cyanobacteria in Extreme Environments. Series: Cellular Origin, Life in Extreme Habitats and Astrobiology, Vol. 11, Springer, pp. 267-284, Dordrecht.

Lukešová, A. \& A. Nováková, 2009: Interactions between the soil micro-flora and invertebrates in Slovak and Moravian caves.- In: Tajovský, K. et al. (eds.) Contributions to soil zoology in Central Europe, Proceedings of the $9^{\text {th }}$ Central European workshop on soil zoology, $17^{\text {th }}-20^{\text {th }}$ April 2007, České Budějovice, Institute of Soil Biology, Biology Centre, Academy of Sciences of the Czech Republic, 89-96, České Budějovice.

Malik, S., Beer, M., Megharaj, M. \& R. Naidu, 2008: The use of molecular techniques to characterize the microbial communities in contaminated soil and water.- Environment International, 34, 2, 265-276.

Morita, H., Ushiyama, M., Aoyama, S. \& M. Iwasaki, 2003: Sensitivity and specificity of the Sanita-kun Aerobic Count: Internal validation and independent laboratory study.- Journal of AOAC International, 86, 2, 355-366.

Morita, H., Ushiyama, M., Aoyama, S. \& M. Iwasaki, 2006: Evaluation of the Sanita-kun coliforms, a dehydrated medium sheet for coliform detection. Performance-tested method 100402.- Journal of AOAC International, 89, 2, 399-416.

Moter, A. \& U.B. Gobel, 2000: Fluorescent in situ hybridization-FISH for direct visualization of microorganisms.- Journal of Microbiological Methods, 41, 2, 85-112.

Mulec, J., 2008: Microorganisms in hypogeon: examples from Slovenian karst caves.- Acta Carsologica, 37, 1, 153-160.

Mulec, J., Krištůfek, V. \& A. Chroňáková, 2012a: Comparative microbial sampling from eutrophic caves in Slovenia and Slovakia using RIDA $^{\oplus}$ COUNT test kits.- International Journal of Speleology, 41, 1, 1-8.

Mulec, J., Vaupotič, J. \& J. Walochnik, 2012a: Prokaryotic and eukaryotic airborne microorganisms as tracers of microclimatic changes in the underground (Postojna Cave, Slovenia).- Microbial Ecology, 64, 3, 654-667. 
Nocker, A., Burr, M. \& A.K. Camper, 2007: Genotypic microbial community profiling: A critical technical review.- Microbial Ecology, 54, 2, 276-289.

Northup, D.E., 2009: Cave microbial communities: Is protection necessary and possible?- In: White, W.B. (ed.) Proceedings of the $15^{\text {th }}$ International congress of speleology, 16 ${ }^{\text {th }}-26^{\text {th }}$ July 2009, Kerrville, International Union of Speleology, 763-767, Kerrville.

Northup, D.E \& K.H. Lavoie, 2001: Geomicrobiology of caves: a review.- Geomicrobiology Journal, 18, 3, 199-222.

Nichols, D., 2007: Cultivation gives context to the microbial ecologist.- FEMS Microbiology Ecology, 60, 3, 351-357.

Núdziková, L., 2009: Guided available caves in 19992008.- Aragonit, 14, 2, 132-134. [In Slovak]

Núdziková, L. \& L. Gaál, 2011: Attendance accessible caves in 2010.- Aragonit, 16, 1-2, 52. [In Slovak]

Paoletti, M.G., Beggio, M., Dreon, A.L., Pamio, A., Gomiero, T., Brilli, M., Dorigo, L., Concheri, G., Squartini, A. \& A.S. Engel, 2011: A New foodweb based on microbes in calcitic caves: The Cansiliella (Beetles) case in Northern Italy.- International Journal of Speleology, 40, 1, 45-52.

R-Biopharm, 2012: Microbiology/Hygiene.- [Online] Available from: http://www.r-biopharm.com/ [Accessed $8^{\text {th }}$ May 2012].

Ritz, K., 2007: The plate debate: Cultivable communities have no utility in contemporary environment microbial ecology.- FEMS Microbiology Ecology, 60, 3, 358-362.

Ronaghi, M., 2001: Pyrosequencing sheds light on DNA sequencing.- Genome Research, 11, 3-11.

Summers Engel, A., 2012a: Chemotrophy.- In: White, W.B. \& D.C. Culver (eds.) Encyclopedia of Caves. Elsevier, pp. 125-134, Chennai.
Summers Engel, A., 2012b: Microbes.- In: White, W.B. \& D.C. Culver (eds.) Encyclopedia of Caves. Academic Press, pp. 490-499, Chennai.

Šustr, V., Elhottová, D., Krištůfek, V., Lukešová, A., Nováková, A., Tajovský, K. \& J. Tříska, 2005: Ecophysiology of cave isopod Mesoniscus graniger (Frivaldszky, 1865) (Crustacea: Isopoda).- European Journal of Soil Biology, 41, 3-4, 69-75.

Tiedje, J.M., Assuming-Brempong, S., Nusslein, K., March, T.L. \& S.J. Flynn, 1999: Opening the black box of soil microbial diversity.- Applied Soil Ecology, 13, 2, 109-122.

Torsvik, V., Daae, F.L., Sandaa, R. \& A.L. Ovreas, 1998: Review article: novel techniques for analyzing microbial diversity in natural and perturbed environments.- Journal of Biotechnology, 64, 1, 53-62.

Uhrin, M., Hapl, E., Andreas, M., Benda, P., Bobáková, L., Hotový, J., Matis, Š., Obuch, J., Pjenčák, P. \& A. Reiter, 2002: Overview of wintering bats Muran plateau.- Vespertillio, 6, 103-130. [In Slovak]

van Elsas, J.D., Torsvik, V., Hartmann, A., Øvreås, L. \& J.K. Jansson, 2006: The bacteria and archaea in soil.In: Elsas van, J.D. et al. (eds.) Modern Soil Microbiology. CRC Press, pp. 83-105, Boca Raton.

van Elsas, J.D., Chiurazzi, M., Mallon, C.A., Elhottová, D., Krištůfek, V. \& J.F. Salles, 2012: Microbial diversity determines the invasion of soil by a bacterial pathogen.- Proceedings of National Academy of Science USA, 109,1159-1164.

Verhoeff, A., (ed), 1993: Biological particles in indoor environments, Environment and quality of life series.- Commission of European Communities, EUR 14988, Report No. 12, 22-34.

Višňovská, Z., 2007: The caves of the Demänovská valley - important bat wintering sites.- Aragonit, 12, 54-61. [In Slovak with English abstract] 